\title{
Contrasting Stress Response of Male Arctic Ground Squirrels and Red Squirrels
}

\author{
RUDY BOONSTRA* AND CAROLYN J. MCCOLL \\ Division of Life Sciences, University of Toronto at Scarborough, \\ Scarborough, Ontario, Canada M1C $1 A 4$
}

\begin{abstract}
A hormonal-challenge protocol was used to compare the stress response of males of Arctic ground squirrels and red squirrels during the breeding season (May). These squirrels live in the same boreal forest of the Yukon, but have very different life histories and utilize the forest in markedly different ways. Red squirrels had levels of total cortisol, maximum corticosteroidbinding capacity, and free cortisol that were 5, 7, and 2 times, respectively, those of Arctic ground squirrels. Red squirrels were resistant to suppression by an artificial glucocorticoid, dexamethasone (DEX); Arctic ground squirrels were not. Cortisol levels in red squirrels responded slowly but continuously to the ACTH injection; Arctic ground squirrels responded rapidly and then stabilized. Testosterone levels in red squirrels were extremely sensitive to the challenge, being suppressed by both DEX and ACTH; levels in Arctic ground squirrels were resistant to the challenge, being modestly suppressed by DEX and stimulated by ACTH. Energy mobilization, as measured by glucose and free fatty acid responses, was not affected. Red squirrels had four times the levels of white blood cells and higher proportions of lymphocytes and lower proportions of eosinophils than Arctic ground squirrels, indicating that the latter were in worse condition immunologically. Our evidence suggests that the functions associated with the hypothalamic-pituitary-adrenal axis are compromised in breeding male Arctic ground squirrels, but not in red squirrels. We propose that in male red squirrels this axis has evolved in the context of a stable social system based on long-lived animals with individual territories which are needed to deal with unpredictable winter food supplies. In contrast, Arctic ground squirrels escape the rigors of winter by hibernation and this hormonal axis has evolved in short-lived males in the context of intense intra-sexual competition in a social system based on female kin groups and regular male dispersal to avoid inbreeding. J. Exp. Zool. 286:390-404, 2000. (c) 2000 Wiley-Liss, Inc.
\end{abstract}

Habitat has been regarded as the template for the evolution of life history traits (Southwood, '77, '88) and though habitat cannot be the sole determinant for any particular suite of traits (Stearns, '92), it clearly plays a major role. The endocrine system is a major pathway through which life history decisions to reproduce, to grow, or to put energy into storage are implemented, and should be a critical component adapting organisms to particular habitats and thus under strong selection pressure (Finch and Rose, '95). The hypothalamicpituitary-adrenocortical (HPA) axis is a pivotal one in all vertebrates for three main reasons. First, it is a critical axis involved in normal day-to-day activities associated with the diurnal cycle of waking such as increased locomotion, exploratory behavior, appetite, and food-seeking behavior (McEwen et al., '88). Second, it permits short-term adaptation to maintain survival in the face of acute, environmental stressors (Sapolsky, '92). Stress can be defined as the set of responses by mammals to potentially harmful environmental challenges (Selye, '46; Lee and McDonald, '85). The role of the HPA is essentially catabolic, with acute stressors causing a stimulation of hepatic gluconeogenesis, an inhibition of glucose uptake by peripheral tissues, a suppression of the inflammatory response, a suppression of immune response, and an inhibition of secretion of several hormones and neuropeptides (Munck et al., '84). Thus this axis shunts energy to muscles and away from other tissues for the "flight or fight response." Third, the axis is central to certain long-term evolutionary adaptations to particular ecological and habitat pressures (e.g., a collapse of the immune and inflammatory responses caused by a dysfunc-

Grant sponsors: Natural Sciences and Engineering Research Council of Canada and the University of Toronto.

*Correspondence to: R. Boonstra, Division of Life Sciences, University of Toronto at Scarborough, Scarborough, Ontario, Canada, M1C 1A4. E-mail: boonstra@scar.utoronto.ca

Received 22 January 1999; Accepted 20 July 1999 
tional stress axis associated with semelparity in small mammals in Australia: Bradley et al., '80; McDonald et al., '81; Bradley, '87; reduced stress response in birds in unpredictable Arctic environments: Silverin et al., '97). Our objective in this study was to examine how the HPA axis differs in breeding males of two related rodents with markedly different life histories living in the same forest but using two different habitat niches: a largely arboreal one and a terrestrial, semi-fossorial one.

The Sciuridae are the squirrel family in the order Rodentia and are well represented in North America (Hafner, '84). In the subfamily Sciurinae, there are three tribes: the Tamiini (the chipmunks), the Sciurni (the tree squirrels), and the Marmotina (the burrowing squirrels-marmots, ground squirrels, and prairie dogs). The tree squirrels diverged from the burrowing squirrels at the end of the Oligocene about 30 million years ago (Hafner, '84) and thus have had a long history of independent evolutionary adaptation. We examined the stress response of a representative tree squirrel-the red squirrel, Tamiasciurus hudsonicus; and a representative burrowing squirrelthe Arctic ground squirrel, Spermophilus parryii, and how differences in this response may reflect long-term adaptation to these two modes of existence. Though their common, phylogenetic origin could constrain their physiological stress responses (for a review of the problems and strengths of phylogenetic comparative methods, see Martins and Hansen, '96), we expect that these squirrels are more likely to be influenced by recent selective history because of their different social structure and modes of existence than by ancient conditions and thus not likely to show phylogenetic correlation directly.

The red squirrel is a tree squirrel whose distributional range covers the entire boreal forest of North America (Banfield, '74). These squirrels are bold, highly vocal, and appear to have boundless energy as they move rapidly through the coniferous trees, aggressively defending their territories and challenging all intruders (including humans) with their calls. They are medium-sized (ca. 250 g), diurnal granivores specializing in seeds from pine and spruce, but also eating a variety of other vegetable matter (conifer buds and flowers, lichens, berries, and mushrooms) (M.C. Smith, '68; Gurnell, '87; Obbard, '87) together with a sizable component of animal matter such as insects, bird eggs, nestling birds, and snowshoe hare leverets (O'Donoghue, '94). They defend individual, non- overlapping territories year-round (C. Smith, '68; Price et al., '90) and these are essential for overwinter survival (Larsen and Boutin, '94). Thus, they are asocial except during mating. The breeding season lasts from March through early August, with most females in the southern Yukon producing only one litter between March and June (O'Donoghue and Boutin, '95), but some conceiving for a second attempt if their first litter fails (Boutin, personal communication). Virtually all males (including yearlings) are in reproductive condition from March to May and then the proportion declines until early August, when all become nonreproductive (Banfield, '74; Boutin, personal communication). Red squirrels are longlived small mammals (living up to 4-7 years), with the sex ratio being skewed toward males in the older age classes (Kemp and Keith, '70; Rusch and Reeder, '78). A dominant feature of the boreal forest ecosystem is the 10-year snowshoe hare cycle (Keith, '90; Krebs et al., '95) and many mammalian herbivores in this ecosystem fluctuate in synchrony with the hares because of the effects of predation. However, red squirrel populations are largely unaffected by the hare cycle, implying that predation plays a lesser role in their demography (Stuart-Smith and Boutin, '94; Boutin et al., '95).

The Arctic ground squirrel is North America's northernmost hibernator, spending from 60-75\% of the year inactive in its burrow (McLean and Towns, '81). It is found primarily in Arctic alpine and mainland Arctic tundras, and in the northwest, also in grassland areas within the boreal forest (Banfield, '74), where their range overlaps that of the red squirrel. Arctic ground squirrels are medium-sized (ca. 500-750 g) diurnal burrowing herbivores that seldom move far from the protection of the burrow and readily retreating to it when threatened by predators or the elements. They live in small groups of related females with no more than one territorial male per group (Lacey, '91). Males emerge from hibernation in early to mid-April and adult females from midApril to early May, with mating taking place within 3-4 days of female emergence (McLean and Towns, '81; Lacey et al., '97). During the mating period, territoriality breaks down with males roaming widely and competing intensely for access to females (Lacey, '91). Both sexes are promiscuous and many litters are multiply sired (Lacey et al., '97). Virtually all males (including yearlings) are in breeding condition from April to mid-May (Lacey, '91; Barnes, '96). To avoid inbreeding, all adult males and all juveniles that 
will mature the next year disperse in summer to new sites prior to hibernation (Lacey, '91; Byrom, '96). The lifespan of Arctic ground squirrels is not well known, especially in males because of their yearly dispersal. In general, females appear to be long-lived (females 7 years old have been caught in our populations; Karels, personal communication) and males short-lived. In virtually all ground squirrel species, there is a significant skewing of sex ratios in favor of females in breeding animals (Boag and Murie, '81), indicating much higher mortality rates among males. Michener and McLean ('96) found that in Richardson's ground squirrel (S. richardsonii), 55\% of the breeding males disappeared immediately after the breeding season and were not seen again. We found that almost half the males present in the spring mating period in our area disappeared shortly thereafter and this appeared not to be due to dispersal (Boonstra et al., unpublished data). They eat a large variety of foods found above ground near their burrows, including seeds of herbs, leaves and flowers of forbs (especially legume species), mushrooms, willows leaves and catkins, grasses, and sage (Lincoln, '72; McLean, '85). Like red squirrels, they readily eat animal matter and may kill to get it (e.g., microtines: Boonstra et al., '90; hare leverets: O'Donoghue, '94). Unlike red squirrels, Arctic ground squirrel populations in the boreal forest are directly affected by the snowshoe hare cycle, declining markedly following the hare decline because of the effects of predation (Hubbs and Boonstra, '97; Karels et al., 2000) and these squirrels appear to be stressed by the risk of predation (McColl, '97; Karels et al., 2000).

To assess the HPA axis of these two squirrel species, we compared the ability of breeding males to respond to a standardized challenge. We used a hormonal-challenge protocol to get an integrated picture of the males' recent physiological past while at the same time overriding the immediate stress response the squirrels were experiencing because of the effects of capture and handling (Boonstra et al., '98). This protocol involved two steps: the dexamethasone suppression test (Kalin et al., '81) followed by the adrenocorticotropic hormone (ACTH) stimulation test. The dexamethasone suppression test assesses whether the brain is registering glucocorticoid levels correctly (dexamethasone is an artificial glucocorticoid) and making the necessary negative feedback adjustment by reducing ACTH release from the pituitary and thus cortisol production from the adrenal. The ACTH stimulation test probes the responsiveness of adrenals directly. Thus this protocol simulated the internal hormonal fluctuations that would normally occur in response to an external environmental stressor. This protocol, or modifications of it, has been successfully applied in studies on stress in a wide variety of species in field studies (e.g., deer: Smith and Bubenik, '90; sparrows: Astheimer et al., '94; snowshoe hares: Boonstra et al., '98). We performed our comparison at a biologically equivalent time in their annual cycle: in early May, males of both species are nearing the end of the mating period (though red squirrel males remain reproductively capable as some females do mate again, as indicated above) and thus any differences occurring between them as a result of different adaptations to their environment should be pronounced.

Given that red squirrels are long-lived and depend on territory ownership for survival, we expect that the stress response in male red squirrels should function to maintain homeostasis at all times, even during the breeding season. In contrast, given that male Arctic ground squirrels are short-lived, compete intensely for access to females, and then disperse, we expect that they may tradeoff survival for reproduction and thus show a stress response that is geared towards maximizing fitness. Thus, we predict that red squirrels should not be chronically stressed by the effects of mating competition, whereas Arctic ground squirrels may be.

\section{MATERIALS AND METHODS}

\section{Study area}

The study site was located in an undisturbed northern boreal forest near Kluane Lake, Yukon Territory, Canada $\left(60^{\circ} 57^{\prime} \mathrm{N}, 138^{\circ} 12^{\prime} \mathrm{W}\right)$ (Boutin et al., '95; Krebs et al., '95). The vegetation in this area is heterogeneous, being dominated by white spruce forests (Picea glauca) having an understory of willow (Salix sp.) and birch (Betula glandulosa) and willow shrub thickets, with lesser contributions of grass meadows and aspen poplar stands (based on air photo analysis, Krebs, unpublished data). The climate is cold continental with the growing season being from mid May through mid August and snow cover occurring from October through early May. Average January and July temperatures are $-21.9^{\circ} \mathrm{C}$ and $12.8^{\circ} \mathrm{C}$, respectively, and total annual precipitation averages $284 \pm 10 \mathrm{~mm}$, with most of it falling as snow (data from Burwash Landing Climatological Station 1967-1995). 


\section{Experimental animals and trapping protocol}

A random sample of breeding male ground squirrels $(\mathrm{N}=10,454.0 \pm 10.7 \mathrm{~g}[ \pm 1 \mathrm{SE}])$ was captured along the Old Alaska Highway and along the Alaska Highway May 2-4, 1996. All but one were new animals that had not been trapped before and the old one was a tagged animal which had dispersed to the site from a nearby trapping grid, probably during the previous summer. A random sample of breeding male red squirrels $(\mathrm{N}=$ $10,236.0 \pm 4.1 \mathrm{~g}$ ) was captured on May 6, 1996, on a ground squirrel live-trapping grid (Control A; see Hubbs and Boonstra, '97 for a description of the grid, which was within $10 \mathrm{~km}$ of where the ground squirrels were captured for this study). All but one were tagged and thus had been captured before. However, the grid was last trapped in early September 1995 and thus the squirrels had not been captured for 8 months. In both species, breeding males were defined as having enlarged testes descended into a dark scrotum. Animals were captured in Tomahawk live-traps baited with peanut butter and set adjacent to burrows in the shade for ground squirrels and placed at alternate stakes on a $10 \times 10$ grid ( $30.5 \mathrm{~m}$ between grid stakes) for red squirrels. For ground squirrels, traps were set between 8:00 hr and 9:00 hr and were checked every $3 \mathrm{hr}$. For red squirrels, traps were set at 7:00 $\mathrm{hr}$ and were checked $1 \mathrm{hr}$ later. All males were weighed (Pesola $\pm 5 \mathrm{~g}$ ) and transferred to a dimly lit, quiet laboratory at the Arctic Institute Base (ca. 7-10 km away). They were housed in traps, covered with burlap to minimize disturbance and exposure, and allowed to habituate to the laboratory surroundings (unheated room, approximately $15^{\circ} \mathrm{C}$ ) minimum of $1.5 \mathrm{hr}$ before the experiment started.

\section{Anesthetic and injections}

All animals were anesthetized prior to the collection of blood samples. The animals were temporarily anesthetized with the inhalant anesthetic Forane (isoflurane) using the bell-jar technique (McColl and Boonstra, 2000). Anesthesia was induced within 15-30 sec and blood samples were collected within 1 min of induction.

Each squirrel was bled by suborbital sinus puncture using a glass heparinized pipette. Five blood samples were collected over a 4 -hr period. Blood from the first sample (called the BASE bleed, 300$500 \mu \mathrm{l}$ ) was used to obtain baseline estimates of blood parameters. Immediately following the col- lection of the BASE sample, animals were injected by cardiac puncture using $2.22 \mathrm{~cm} 26$ gauge needles with non-opaque hubs (as recommended by B. Barnes, University of Alaska, Fairbanks) with $0.4 \mathrm{mg} / \mathrm{kg}$ dexamethasone sodium phosphate (Sabex, Montreal, Canada). The second blood sample (called the DEX bleed, 200-300 $\mu \mathrm{l}$ ) was collected $2 \mathrm{hr}$ later and was immediately followed by an intramuscular injection into the thigh of 4 IU/kg of synthetic ACTH (Synacthen Depot, CIBA, Ontario, Canada). Subsequent blood samples were collected at 30,60, and 120 min post-ACTH injection (called the P30, P60, and P120 bleeds, respectively and all 200-300 $\mu \mathrm{l}$ ). At the end of the study, the red squirrels were sacrificed and autopsied; the Arctic ground squirrels were used in another study and subsequently released.

\section{Hematology}

Blood samples were collected in heparinized 75 $\mu l$ microhematocrit tubes (Red-Tips: Fisher Scientific Co.) and were allowed to flow into $0.5 \mathrm{ml}$ Eppendorf tubes. Glucose concentrations in $\mathrm{mg} /$ dl were measured after each bleed by the glucose oxidase/peroxidase reaction (Accu-chek III, Boehringer-Mannheim, Mannheim, Germany). The accuracy of the device was compared with standard control solutions and the values were within $20 \%$ for the low control solution (51 mg/dl) and 10\% for the high control solution $(292 \mathrm{mg} / \mathrm{dl})$; these are within the admissible range. Glucose concentration was generally measured within 5 min and always within 15 min of blood collection.

Hematology was conducted only on the first bleed of each animal, except for glucose concentrations, which were measured after every bleed. Hematocrit was measured as the percent packed red-blood cell volume (PCV; hematocrit) in 75- $\mu \mathrm{l}$ heparinized microhematocrit tubes sealed with Critoseal. PCV was measured on two samples per squirrel after a 5-min centrifugation at 13,460g on an IEC Micro-Hematocrit Centrifuge, Model MB. Two blood smears for identification and quantification of white blood cell type were prepared from the BASE sample of each animal. Blood was vortexed prior to making the smear to provide an even distribution of cells. The smears were fixed and stained with a modified Wright Stain technique using Diff-Quik (Baxter Health Care Corp., FL). Differential white blood cell counts were based on counts of 100 leucocytes. The remaining blood was centrifuged at $8800 \mathrm{~g}$ for $8 \mathrm{~min}$ in an Eppendorf Micro Centrifuge, the plasma was removed, frozen, and stored at $-20^{\circ} \mathrm{C}$ until it was 
transported to Toronto, where the plasma was stored at $-70^{\circ} \mathrm{C}$ until analysis.

\section{Cortisol assay}

We only analyzed for cortisol as this is the primary adrenal glucocorticoid in these squirrels (Boonstra, unpublished data). We measured total plasma cortisol by the radioimmunoassay method used by Boonstra and Singleton ('93), using anticortisol antibody A-155 obtained from Western Chemical (Fort Collins, CO). Blank values of charcoal-stripped plasma and of solvent did not differ significantly from zero. The assay was sensitive to $10 \mathrm{pg} / 10 \mu \mathrm{l}$. The mean recovery of $\left[1,2,6,7-{ }^{3} \mathrm{H}\right]$ cortisol (Amersham) added to plasma was $105 \%$ ( \pm 1.2$)$ (range $100-107 \%$ ). The intra- and inter-assay coefficients of variation were $4 \%$ and $15 \%$, respectively.

Critical to understanding the potential impact of changing cortisol levels is knowing how much is actually free and not bound to its main carrier protein, corticosteroid-binding globulin (CBG), as it is primarily the free cortisol which appears to be biologically active (Rosner, '90). Thus, it is critical to determine how much plasma cortisol is free as opposed to the total present. However, CBG does not simply appear to act as a buffering mechanism for cortisol in plasma, but also acts as a carrier protein for cortisol, interacts with cell surface receptors, and may be internalized in the cell (Rosner, '90). To calculate the concentrations of free cortisol we used the calculation procedures outlined in Tait and Burstein ('64) and for these calculations we need to know three values: the albumin concentration in plasma (albumin also binds cortisol and has high capacity but low affinity), the ratio of albumin-bound to free cortisol, and the affinity constant of CBG for cortisol. Pure albumin was obtained through the trichloroacetic acid method described in Michael ('62). This albumin was then used as a standard to calculate the concentration of albumin in plasma by the chromographic method of Debro et al. ('57). We calculated that Arctic ground squirrels have $2.54 \mathrm{~g}$ albumin per $100 \mathrm{ml}$ plasma. The ratio of albumin-bound to free cortisol in a $1 \%$ solution was 0.19 . The CBG affinity constant for squirrels was measured in a microdialysis system (Englund et al., '69) modified to 12 chambers (AJ Bradley, personal communication) using $60-\mu \mathrm{l}$ samples of plasma diluted 1:5 with a phosphosaline buffer (0.05 M, pH 7.4). In this system, equilibrium was established in $12 \mathrm{hr}$ at $37^{\circ} \mathrm{C}$ following which the specific activity of dialysate and sac contents was measured in a scintillation counter. The concentration of CBG-bound and unbound cortisol was calculated by the method described in Paterson and Hills ('67) and the CBG affinity constant calculated by the Scatchard analysis (Scatchard, '49). We calculated the CBG-binding constant of the Arctic ground squirrel to be $4.505 \times 10^{7} \mathrm{M}^{-1}$.

Plasma corticosteroid-binding globulin (CBG) was measured as the maximum corticosteroid binding capacity (MCBC) using $\left[1,2,6,7-{ }^{3} \mathrm{H}\right]$ cortisol (Amersham), diluted in cold cortisol to known specific activity 5- to 20 -fold in excess of the expected capacity (see McDonald et al., '81 for details of method). We allowed for the contribution of the endogenous cortisol in the sample. The highaffinity fraction in a $10-\mu l$ sample of plasma, diluted in $0.5 \mathrm{ml}$ phosphate buffer, was measured by liquid scintillation after separation from the free- and albumin-bound fractions with dextrancoated charcoal. The high-affinity-bound cortisol was then calculated knowing the specific activity and the radioactivity in the bound fraction.

\section{Androgen assay}

Plasma testosterone plus dihydrotestosterone was measured by radioimmunoassay. The protocol for the radioimmunoassay of testosterone was based on that of Abraham et al. ('71) with double diethyl ether extractions of duplicate plasma samples (Boonstra and Boag, '92). Each plasma sample $(25 \mu \mathrm{l})$ was treated with $20 \mu \mathrm{l} \mathrm{NH} \mathrm{NH}_{4} \mathrm{OH}$, to saponify triglycerides, prior to extraction. Two quality control samples were run in duplicate with each assay. Blank values of solvents were also run with each assay and did not differ significantly from zero. The intra- and inter-assay coefficients of variation for testosterone were $5 \%$ and $6 \%$, respectively.

\section{Free fatty acid analysis}

Total free fatty acids (FFA) were measured by the method of Laurell and Tibbling ('67). To obtain adequate levels of FFA, we extracted $25 \mu \mathrm{L}$ of plasma.

\section{Statistical analysis}

Data are expressed as means \pm SE. We used Cochran's test (Winer, '71) as recommended by Day and Quinn ('89) to test for homogeneity of variance. The hormone and glucose data did not meet the assumption of homogeneous variances, and we used the $\log (x+1)$ transformation to make the variances homogeneous. All ANOVAs were performed using SuperANOVA (Gagnon et al., '91). A 
repeated-measures ANOVA was used for all parameters that were measured serially in the hormonal challenge test. In a repeated-measures design, the values recorded from the same animal will be correlated with each other and thus are not independent as assumed by ANOVA. To compensate for this, we used the conservative Greenhouse-Geisser epsilon to adjust the degrees of freedom before calculating the probabilities as recommended by Keppel ('82). We used the TukeyKramer multiple comparison post-hoc test to examine the significance of main effects.

\section{RESULTS}

\section{Plasma cortisol levels}

The repeated-measures ANOVA indicated that, averaged over the entire experiment (after the removal of variance owing to within-subject effects), red squirrels had significantly higher levels of total cortisol (5 times), MCBC (7 times), and free cortisol (2 times) than did Arctic ground squirrels (Fig. 1, Table 1). Thus, red squirrels produced much more cortisol than Arctic ground squirrels, but also had much greater buffering capacity to compensate for those higher levels, though they still were exposed to about double the amount of free cortisol.

The within-subjects effects examining the responses to the injections over time showed the same differences between the two species for each of the above three components, but the interpretation is complicated by the significant interactions between species and time (Fig. 1, Table 2). We make four points with respect to this analysis. First, even at the BASE bleed before the injections, red squirrels had markedly higher levels
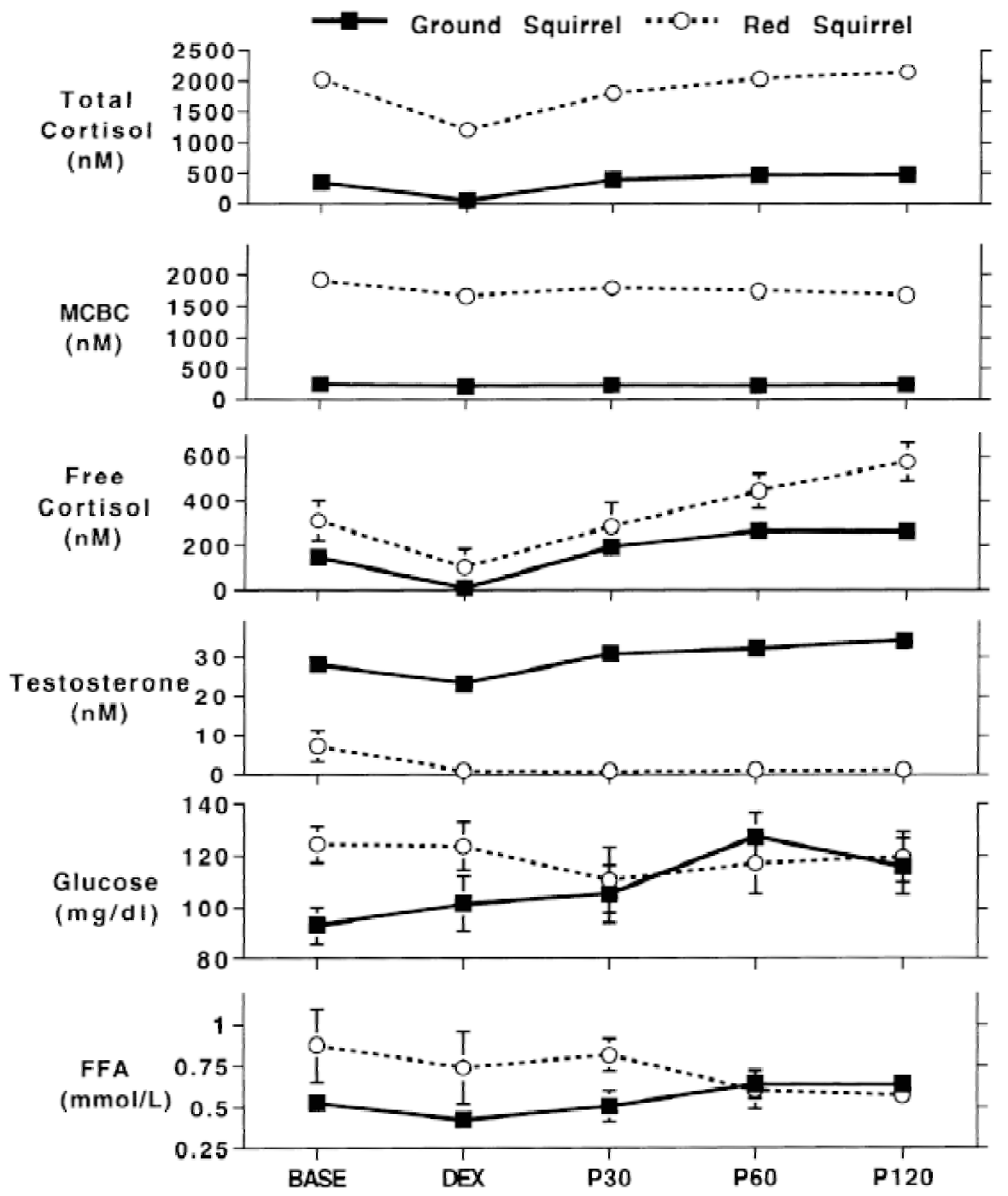

Fig. 1. Responses over time in plasma concentrations of various parameters (MCBC, maximum corticosteroid-binding capacity; FFA, free fatty acids) in breeding male Arctic ground squirrels and red squirrels $(\mathrm{N}=10$ males for both species). BASE bleeds indicate initial values, DEX indicates values $2 \mathrm{hr}$ after the dexamethasone injection, and P30, P60, and P120 indicate values 30,60 , and 120 min after ACTH injection. Error bars $( \pm 1 \mathrm{SE})$ are presented for all means and for those not visible, the error bar is smaller than the size of the symbol. 
$T A B L E$ 1. The average effects (means $\pm S E, N=10$ in both species) of the hormonal challenge on Arctic ground squirrels and red squirrels

\begin{tabular}{lcr}
\hline & $\begin{array}{c}\text { Arctic } \\
\text { ground squirrels }\end{array}$ & $\begin{array}{c}\text { Red } \\
\text { squirrels }\end{array}$ \\
\hline Cortisol (nM/liter)* & $345.6 \pm 20.1$ & $1846.7 \pm 76.0$ \\
MCBC (nM/liter)* & $233.9 \pm 7.4$ & $1669.4 \pm 40.2$ \\
Free cortisol (nM/liter)* & $175.9 \pm 15.5$ & $343.6 \pm 32.4$ \\
Testosterone (nM/liter)* & $29.7 \pm 1.39$ & $2.2 \pm 0.87$ \\
Glucose (mg/dl) & $108.7 \pm 4.58$ & $119.1 \pm 4.48$ \\
Free fatty acids (mM/liter) & $0.55 \pm 0.04$ & $0.72 \pm 0.07$ \\
\hline
\end{tabular}

$* P<0.0001$.

TABLE 2. Repeated measures ANOVA testing differences between male Arctic ground squirrels and red squirrels in response to the hormonal-challenge protocol ${ }^{1}$

\begin{tabular}{|c|c|c|c|c|}
\hline Source & $\mathrm{df}$ & MS & $\mathrm{F}$ & $P$ \\
\hline \multicolumn{5}{|l|}{ Total cortisol } \\
\hline Treatment & 1 & 16.1 & 880.8 & 0.0001 \\
\hline Subject (group) & 18 & 0.02 & & \\
\hline Time & 4 & 1.4 & 77.4 & 0.0001 \\
\hline Time $\times$ treatment & 4 & 0.42 & 22.7 & 0.0001 \\
\hline Error & 72 & 0.02 & & \\
\hline \multicolumn{5}{|l|}{ Free cortisol } \\
\hline Treatment & 1 & 3.2 & 35.8 & 0.0001 \\
\hline Subject (group) & 18 & 0.09 & & \\
\hline Time & 4 & 4.6 & 71.6 & 0.0001 \\
\hline Time $\times$ treatment & 4 & 0.53 & 8.4 & 0.0008 \\
\hline Error & 72 & 0.06 & & \\
\hline \multicolumn{5}{|l|}{ MCBC } \\
\hline Treatment & 1 & 19.3 & 709.2 & 0.0001 \\
\hline Subject (group) & 18 & 0.03 & & \\
\hline Time & 4 & 0.009 & 3.3 & 0.04 \\
\hline Time $\times$ treatment & 4 & 0.002 & 0.75 & \\
\hline Error & 72 & 0.003 & & \\
\hline \multicolumn{5}{|l|}{ Testosterone } \\
\hline Treatment & 1 & 16.7 & 285.4 & 0.0001 \\
\hline Subject (group) & 18 & 0.06 & & \\
\hline Time & 4 & 0.05 & 3.1 & 0.09 \\
\hline Time $\times$ treatment & 4 & 0.06 & 3.5 & 0.11 \\
\hline Error & 72 & 0.02 & & \\
\hline \multicolumn{5}{|l|}{ Glucose } \\
\hline Treatment & 1 & 2724.8 & 0.9 & \\
\hline Subject (group) & 18 & 2955.7 & & \\
\hline Time & 4 & 733.3 & 1.4 & \\
\hline Time $\times$ treatment & 4 & 1336.2 & 2.5 & 0.08 \\
\hline Error & 72 & 542.9 & & \\
\hline \multicolumn{5}{|l|}{ Free fatty acids } \\
\hline Treatment & 1 & 1.04 & 2 & \\
\hline Subject (group) & 18 & 0.018 & & \\
\hline Time & 4 & 0.003 & 0.5 & \\
\hline Time $\times$ treatment & 4 & 0.012 & 2.2 & \\
\hline Error & 72 & 0.005 & & \\
\hline
\end{tabular}

${ }^{1}$ The probability estimates of the within-subject (time) analysis were adjusted using the Greenhouse-Geisser estimate. All absent probability values are nonsignificant, but those just above significance are also given. than Arctic ground squirrels for all three components (Fig. 1). Second, though both species responded to the dexamethasone injection by a reduction in free cortisol levels, levels in Arctic ground squirrels fell to $6 \%$ of baseline levels (from 147.3 at BASE to $8.6 \mathrm{nM}$ /liter at DEX) whereas levels in red squirrels fell to only $33 \%$ of baseline levels (from 311.6 to $103.3 \mathrm{nM}$ /liter, respectively). Thus, red squirrels showed dexamethasone resistance, whereas Arctic ground squirrels did not. Third, though both species also showed the capacity to respond to the ACTH injection, levels of free cortisol increased by P30 in Arctic ground squirrels to 22 times that of DEX levels whereas levels in red squirrels increased by only 2.8 times. However, levels in ground squirrels essentially stabilized over the next 90 min whereas those of red squirrels kept increasing so that by P120, the levels in both species were about 1.8 times those of baseline levels. Thus, the significant interaction effect (Table 2) was the result of a different pattern of response to the two injections by red squirrels than by Arctic ground squirrels. Fourth, MCBC levels showed a small, but significant decline over the $4 \mathrm{hr}$ of the experiment (Table 2), with levels in red squirrels declining $12 \%$ and in Arctic ground squirrels declining $4 \%$.

\section{Plasma testosterone levels}

Arctic ground squirrels had much higher testosterone levels than red squirrels: at BASE they were about 4 times higher and by the P120, they were about 30 times higher. The repeated-measures ANOVA indicated that, averaged over the entire experiment (after the removal of variance owing to within-subject effects), Arctic ground squirrels had significantly higher levels of testosterone than red squirrel (Fig. 1, Tables 1 and 2 ). The within-subjects effects examining the responses to the injections over time were not significant for plasma testosterone, though the moderately low $P$ values $(<0.10)$ suggest there may have been a biological difference, though not a statistical one, and that the latter would have occurred if sample sizes had been larger. Testosterone levels fell following the dexamethasone injection, but the size of the decline was markedly different in the two species. Levels in Arctic ground squirrels fell only 18\% (from 28.14 to 23.19 $\mathrm{nM} /$ /iter) whereas levels in red squirrels fell $87 \%$ (from 7.21 to $0.91 \mathrm{nM} /$ liter). After the injection of ACTH, levels of testosterone in ground squirrels increased by about 1.5 times over the next $2 \mathrm{hr}$ so that by P120, levels were about $21 \%$ above 
BASE levels. In contrast, levels in red squirrels increased by about 0.25 times over the next $2 \mathrm{hr}$ so that by P120, levels were $84 \%$ below BASE levels. Thus, Arctic ground squirrels had much higher testosterone levels both initially and over the entire length of the experiment than did red squirrels, with levels falling after the DEX injection and increasing after the ACTH injection; red squirrels followed the same pattern following the DEX injection, but showed no recovery after the ACTH injection.

\section{Plasma glucose and free fatty acid levels}

The repeated-measures ANOVA indicated the experiment had no effect on either glucose or FFA mobilization (Fig. 1; Tables 1 and 2), either when examined as an average over the entire experiment or as a within-subjects effect. However, glucose levels were significantly higher in red squirrels than in Arctic ground squirrels at BASE (one-way ANOVA, $\left.F_{1,18}=9.59 ; P=0.006\right)$. Figure 1 does suggest that for both glucose and FFA, red squirrels may have had higher levels for the first $2 \mathrm{hr}$ of the experiment (at both the BASE and DEX bleeds), but high variation among red squirrels for FFA and among both species for glucose at the DEX bled, prevent any statistical effect from emerging. Thus, in general, the experimental treatment appeared to have little effect on energy mobilization.

\section{Blood parameters}

Hematocrit at the BASE bleed did not differ significantly between Arctic ground squirrels (39.9\% $\pm 1.32)$ and red squirrels $(43.2 \% \pm 1.55)(t=1.62$; df $18 ; P=0.12$ ). Arctic ground squirrels had significantly higher concentrations of eosinophils and lower concentrations of lymphocytes than red squirrels; monocyte and neutrophil levels were similar (Table 3). Arctic ground squirrels had less than one quarter as many white blood cells per field of view on slides with the blood smears than did red squirrels.

\section{DISCUSSION}

Arctic ground squirrels and red squirrels are superficially similar in that they are both members of the Sciuridae family and live in the same boreal forest in the southern Yukon, but they have such different modes of existence (semi-fossorial versus arboreal) and life histories that they are more dissimilar to each other in many respects than they are to other herbivores also living in this forest. These dissimilarities are also reflected in their response to the same hormonal challenge. Male red squirrels had levels of total cortisol, $\mathrm{MCBC}$, and free cortisol that were 5, 7, and 2 times, respectively, those of male Arctic ground squirrels. Red squirrels showed dexamethasone resistance; Arctic ground squirrels did not. Total and free cortisol levels in red squirrels responded only slowly but continuously to the ACTH injection; Arctic ground squirrels responded rapidly and then stabilized. Red squirrels had low testosterone levels at the BASE bleed that were markedly suppressed both by DEX and by the ACTH-induced increase in cortisol; Arctic ground squirrels had high testosterone levels at the BASE that were modestly depressed by DEX and stimulated by the ACTH-induced increase in cortisol. Energy mobilization, as reflected by glucose and FFA levels (Fig. 1), was not different between the two species (though baseline levels of glucose were higher in red squirrels), indicating that the differences in adrenal response were not tightly coupled with that of energy mobilization. Our measures of the immune response (Table 3) were also not inversely related to the cortisol levels, indicating that male Arctic ground squirrels were in worse condition than red squirrels. Thus, red squirrels were markedly different from Arctic ground squirrels in measures related to the immediate stress response, to the testosterone response, and to the immune response, but not to energy mobilization.

Before we discuss these results, we deal with

TABLE 3. Concentration and composition of the major types of white blood cells from blood smears of breeding male Arctic ground squirrels and red squirrels ${ }^{1}$

\begin{tabular}{lccccc}
\hline & \multicolumn{4}{c}{ White blood cell type (\%) } & Cells per field of view \\
\cline { 2 - 5 } Species & Neutrophils & Lymphocytes & Monocytes & Eosinophils & $0.9 \pm 0.2^{* *}$ \\
Ground squirrel & $64.0 \pm 1.0$ & $31.9 \pm 1.0^{*}$ & $2.2 \pm 0.4$ & $1.9 \pm 0.5^{*}$ & $0.3 \pm 0.2$ \\
Red squirrel & $64.0 \pm 0.7$ & $34.6 \pm 0.7$ & $1.1 \pm 0.3$ & $0.3 \pm 0.2$ & $4.3 \pm 0.4$ \\
\hline
\end{tabular}

${ }^{1}$ Values are expressed as means $\pm \mathrm{SE}(\mathrm{N}=10$ males for both). The Mann-Whitney $\mathrm{U}$ and $t$-test were used for comparisons of white blood cell types and cells per field of view, respectively.

$* P<0.05 ; * * P<0.0001$. 
two caveats that may have influenced them. First, virtually all of the red squirrels had been trapped before whereas virtually all of the Arctic ground squirrels had not. However, no animal had been trapped for at least 8 months and thus we think that if there was an experience factor attenuating the stress response of red squirrels, it was probably marginal, especially given the magnitude of the differences between the two species (Fig. 1). Second, were the squirrels already stressed by the trapping procedure and how might this have influenced our results? Ideally, it would be best to perform the hormonal-challenge protocol on animals that had not been stressed by handling and capture. In some species, this is possible (e.g., baboons darted from behind: Sapolsky, '83; birds captured by mist net: Astheimer et al., '94). However, for these squirrels and many other species of mammals, researchers rely on trapping for capture and thus there is a delay between capture and collection of blood samples. The stress response is so rapid that within 3-5 min of capture, corticosteroid levels start increasing significantly (e.g., mammals: Seggie and Brown, '74; Redei et al, '94; birds: Schoech et al., '91). We know that Arctic ground squirrels (Boonstra et al., unpublished data) were stressed by capture and handling, because shot samples indicated that baseline levels of free cortisol, though not of MCBC, were significantly higher (by 4 times) in trapped and handled animals than in shot animals. Testosterone levels, which are normally depressed by stress and thus lower in trapped animals (e.g., in snowshoe hares: Boonstra and Singleton, '93) were also significantly higher in trapped and handled animals. We have not collected shot samples of red squirrels and thus do not know what baseline levels are. However, given their typical behavior in live-traps (rapidly and continually exploring all corners of the trap in an effort to seek an exit; in contrast, ground squirrels appear more docile and less frantic) and when being handled in net bags (red squirrels are much more difficult to handle, vocalize continually, and will readily bite the unwary trapper; ground squirrels are easier to manipulate and, though they will bite, it is easier to avoid), we think red squirrels were more stressed by livetrapping. Our purposes, however, are comparative in nature and since the live-trapping and handling procedures were similar though responses to being trapped were different, we believe our methodology gives a good reflection of the similarities and differences between these two species.
Male red squirrels showed dexamethasone resistance, and this is often a consequence of chronic stress. For example, in males of semelparous dasyurid marsupials that have just finished the intense breeding season and shortly before they all die, the HPA axis is resistant to DEX injections (McDonald et al., '86; Bradley, '90). Subordinate baboons that are chronically stressed by dominants are dexamethasone resistant (Sapolsky, '83). Boonstra et al. ('98) found evidence of dexamethasone resistance associated with the chronic stress of high predation risk in snowshoe hares during the population decline, but not during the population low. However, in many respects, red squirrels appear to be very similar to prairie voles (Microtus ochrogaster), which show chronic, nonpathogenic, dexamethasone resistance and have very high total cortisol and MCBC levels relative to other rodents (both are similar to what we found in red squirrels; Fig. 1) (Taymans et al., '97). One of the primary characteristics of glucocorticoid resistance is elevated HPA function (Chrousos et al., '93) which is found in prairie voles (Taymans et al., '97), guinea pigs (Keightley and Fuller, '96), and some New World primates (Yamamoto et al., '77; Chrousos et al., '82). In breeding male red squirrels our evidence is consistent with similar elevated HPA function, but we do not know whether female red squirrels also show dexamethasone resistance during the breeding season or whether both sexes show resistance during other times of the year as well. Thus, we cannot specifically relate dexamethasone resistance to mating activity by male red squirrels, but it may be associated with the exclusive territoriality of red squirrels.

The levels of binding protein for cortisol (CBG, corticosteroid-binding globulin, our measure of it being MCBC) are critical to determining how much cortisol is free and thus biologically active (Rosner, '90). Levels in breeding male red squirrels were seven times those of Arctic ground squirrels and this gives red squirrels a much larger capacity to deal with increases in cortisol caused by short-term stressors. Normally, CBG levels appear to have little capacity for rapid short-term changes (less than $24 \mathrm{hr}$ ) (except in lagomorphs where capacity can increase rapidly and temporarily owing to increases in FFA - Boonstra et al., '98; Boonstra and Tinnikov, '98), but do decline after $24 \mathrm{hr}$ or more of chronic stress (Dallman et al., '90; Armario et al., '94; Fleshner et al., '95). However, we found that in both squirrel species, MCBC showed significant declines within $4 \mathrm{hr}$ af- 
ter the start of the stress test (a $12 \%$ and $4 \%$ decline in red squirrels and Arctic ground squirrels, respectively; Fig. 1, Table 2). CBG is synthesized in the liver (Brien, '81) and the half-life of CBG in the blood varies from 6.9-14.5 hr in rats (Smith and Hammond), to $13 \mathrm{hr}$ in rabbits (Seralini et al., '89), and to 5 days in humans (Brien, '81). If the half life of CBG in squirrels is comparable to that in rats and rabbits, it is conceivable that with a suppression or reduction in synthesis, declines such as we observed could occur within $4 \mathrm{hr}$ and this would then rapidly affect the amount of free cortisol following chronic stress. Thus, though very high levels of CBG buffer male red squirrels much more from the effects of high levels of free cortisol caused by very short duration stressors, these levels decline rapidly when the duration of the stressor is longer than a few hours.

Psychogenic or physical stressors that cause an increase in glucocorticoid levels are known to suppress male reproduction (Greenberg and Wingfield, '87; Levine et al., '89). We observed a suppression in testosterone in both squirrel species caused by dexamethasone, an artificial glucocorticoid, and in red squirrels, but not Arctic ground squirrels, caused by the ACTH-induced increase in cortisol (Fig. 1). However, the suppression we observed was much more pronounced in red squirrels than in ground squirrels (Fig. 1), with levels in red squirrels falling very low (to about $1 \mathrm{nM} /$ /iter) and remaining there; those in ground squirrels fell after the dexamethasone injection (to about $23 \mathrm{nM} /$ /iter) and then increased to reach levels higher than at the BASE bleed. Suppression of testosterone by dexamethasone has also been observed in other wild mammals (marsupials: Vinson and Renfree, '75; McDonald et al., '86; Bradley, '90; snowshoe hares: Boonstra and Singleton, '93; Boonstra et al., '98). Suppression of testosterone by stress or by ACTH has also been observed (baboons: Sapolsky, '85; snowshoe hares: Boonstra et al., '98). Some species show a transitory increase (30-60 $\mathrm{min})$ in testosterone levels following a stressor (dominant baboons: Sapolsky, '85; less-stressed snowshoe hares: Boonstra et al., '98; well-fed laboratory rats: Mann and Orr, '90), all consistent with the explanation that these animals were in good condition. Why red squirrels showed no transitory increase in testosterone following ACTH is unclear. It is possible that the red squirrels were all in relatively poor condition given that they had just come through an intense phase of competition for mates (many of the females had conceived in April [Boutin, personal communication]) and that the food supplies were at their seasonal low. Their adequate glucose and FFA response (Fig. 1) and their high white blood cell counts (Table 3 ) argue against this and suggest that red squirrel testosterone response is not indicative of condition, but rather a possible reflection that red squirrels are not a typical mammal with respect to the role of testosterone in behavior and physiology.

Chronically high levels of stress hormones can depress reproductive hormones and thus reproduction, particularly in subordinates (Christian, '70; Sapolsky, '92). However, recent evidence from a number of field studies indicates that high levels of the stress hormones do not invariably compromise the ability to reproduce, as dominants or territorial individuals have high levels of corticosteroids and continue to reproduce (e.g., in social mammals: dwarf mongooses, Creel et al., '96; African wild dogs: Creel et al., '97; birds: Wingfield et al., '91). Our evidence indicates that this same relationship applies in male Arctic ground squirrels (Fig. 1). They showed only a very modest decline in testosterone levels in response to DEX and an increase that lasted $2 \mathrm{hr}$ in response to the ACTH-induced increase in free cortisol levels (Fig. 1). Thus, the typical inverse relationship between stress hormones and reproductive hormones appears to be decoupled in males. This has also been observed in two dasyurid species at the height of the breeding season (McDonald et al., '86; Bradley, '90). In dasyurids, this relationship comes at the cost of subsequent male survival, as all die shortly after the breeding season (Bradley et al., '80; McDonald et al., '81; Bradley, '87). In male Arctic ground squirrels, this relationship may also come at the cost of future survival, as many disappear shortly after the breeding season (Byrom 1996; Karels, unpublished data). The evolutionary reasons for this adaptation during the breeding season may be associated with the need by males to maintain high levels of aggressive behavior associated with competition for access to females during the short, intense mating season (both Arctic ground squirrels [Lacey et al., '97] and the dasyurids are promiscuous [Scott and Tan, '85]) and with the need not to have testosterone levels reduced by the negative effects of chronic stress (Lee and Cockburn, '85; Boonstra and Boag, '92). Unlike the situation found in laboratory rodents and in some primates in which there is a poor correlation between testosterone and rates of aggression or dominance (Monaghan and Glickman, '92), our results imply that the 
presence of high levels of testosterone is a prerequisite for mediating aggressive behavior during the mating period (Yahr, '83; Holekamp and Talamantes, '92).

High levels of free cortisol should act as an immunosuppressant (Munck et al., '84; Kelley, '85) and result in lower levels of white blood cells. However, red squirrels had the higher levels of free cortisol both at the baseline bleed than Arctic ground squirrels and thereafter (Fig. 1), yet had about four times the levels of white blood cells than did Arctic ground squirrels (Table 3). The higher levels of free cortisol that we see in red squirrels at the baseline bleed may simply be caused by the rapid responses to the stress of capture and handling and not indicative of typical levels in the wild, whereas the levels of the white blood cells are more likely to be indicative of true levels in the wild. Red squirrels had significantly higher proportions of lymphocytes and lower proportions of eosinophils than did Arctic ground squirrels; the directions of both are indicative of higher stress levels or lower immunity in Arctic ground squirrels. Stress is known to decrease lymphocyte function (Keller et al., '84) and eosinophilia is known to be associated with parasitic worm infections (Bullock and Rosendahl, '84). These results indicate that, in spite of their high levels of cortisol, red squirrels do not appear to be compromised immunologically, whereas Arctic ground squirrels may be. In red squirrels, we do not know how these white blood cell levels compare with animals not affected by the stresses of mating, and the latter would be a useful benchmark against which to assess our results. The levels of white blood cells we see in red squirrels reinforce the idea that this species is glucocorticoid-resistant. Klein et al. ('96) report that in the prairie vole (also glucocorticoid-resistant) cellular immunity is not compromised by high glucocorticoid levels. Thus, male Arctic ground squirrels appear to be in much poorer condition immunologically during the breeding season than red squirrels.

The ability to mobilize energy was not different in the two species, though there was evidence that at least at the base bleed, red squirrels are operating at a higher level of mobilization for both glucose and FFA (Fig. 1). Chronic stress is known to promote gluconeogenesis (the production of new glucose through the breakdown of other body tissues), and this glucose will be stored in the liver as glycogen (Miller and Tyrrell, '95). If these squirrel species were chronically stressed because of the activities of the mating season, we would have expected a higher mobilization of glucose with the hormonal challenge and a reduced mobilization of FFA (as occurred in snowshoe hares under chronic predation stress during the population decline, Boonstra et al., '98). Neither of these things happened. With respect to glucose, we do not know whether the animals were already approaching maximal levels at the base bleed and thus could do no better. With respect to the FFA, we do know from autopsy data that these red squirrel males had no kidney fat $(\mathrm{N}=10)$, and thus assume that they must have been mobilizing FFA from other stores. In contrast, other male Arctic ground squirrels (shot samples) collected on April 26, 1991 had ample fat stores on the right side of the abdominal cavity (mean $=7.91 \pm 1.71 \mathrm{~g}, \mathrm{~N}=9$, Boonstra, unpublished data) and thus had sources from which to sustain activity independent of that stored elsewhere. Thus, independent of having more or less obvious sources of fats or of marked differences in cortisol levels, there were no dramatic differences in energy mobilization.

Hematocrits (\% packed red-blood cell volume) were not different between the two species, though they were about 3\% lower in Arctic ground squirrels and a larger sample size may have resulted in a statistical effect. A number of studies have found that lower hematocrits are associated with poorer condition (Lochmiller et al., '86; Hellgren et al., '93; Boonstra et al., '98).

In summary, breeding male red squirrels are markedly different from breeding male Arctic ground squirrels in many, though not all, functions associated with the HPA axis. Red squirrels have much higher levels of free cortisol and MCBC accompanied by dexamethasone resistance, lower levels of testosterone which are readily suppressed by hormonal stressors, and much higher white blood cell levels than Arctic ground squirrels. They appear not to be stressed by the experiences of the breeding season, whereas Arctic ground squirrel males are. Thus, the red squirrel HPA axis is regulated at a higher setpoint than that of the Arctic ground squirrels and the former experience no pathological consequences from this adaptation (Chrousos et al., '82; Keightley and Fuller, '96; Taymans et al., '97). The stress response in red squirrel males appears designed to maintain homeostasis at all times, even during the breeding season. In contrast, the hormonal and immune responses of Arctic ground squirrel males appear to be adapted to a life history in which there is a tradeoff of long-term survival for reproduction (low 
levels of white blood cells, low MCBC levels, high testosterone levels), with a large proportion of the males disappearing from the population shortly after the breeding season is finished (Karels, unpublished data).

We suggest these differences are directly related to the social systems that have evolved to exploit the primary habitat of these species. The primary habitat of the red squirrel is the boreal forest and their social system centers on individually defended territories from which all others are excluded (C. Smith, '68; Price et al., '90). In contrast, the primary habitat of the ground squirrel is the open grasslands of the Arctic tundra and alpine regions (Banfield '74) and their social system centers on the group territories of related females to which breeding males then temporarily attach themselves (Armitage, '81; Michener, '83; Lacey, '91). The critical factor for red squirrels is their main winter food supply-seeds from conifersand the production of these is highly variable, ranging from years of superabundance (mast years) to years of cone crop failure (M.C. Smith, '68; Kemp and Keith, '70; Rusch and Reeder, '78). To survive, each red squirrel must acquire and protect this critical resource and this requires intense, continuous vigilance associated with yearround defense of individual territories, which selects for long-term survival to even out the variation in food supply. In addition, since red squirrel populations are largely unaffected by predation during the 10-year snowshoe hare cycle (Stuart-Smith and Boutin, '94; Boutin et al., '95), we speculate that their arboreal habits and the coniferous trees in which they live shield them from the effects of most of the suite of predators in our forests. In contrast, the major factor dominating the life of male Arctic ground squirrels is not the rigors of the northern winter, which they escape by hibernation, but the social organization of females (kin groups, and within the boreal forest, limited habitat in term of meadows may augment kin group development) resulting in intense male-male competition during the brief yearly breeding season followed by their subsequent dispersal in summer to avoid inbreeding depression (Holekamp and Sherman, '89). We suggest that the boreal forest is not an optimal habitat for ground squirrels, as ground squirrels are line-ofsight herbivores that engage in vigilance behaviour by utilizing their burrow mounds and other high points to reduce the risk of predation (MacHutchon and Harestad, '90; Hubbs et al., '96). The boreal forest limits predator detection and as a result, Arctic ground squirrel populations fluctuate in synchrony with the hare cycle (Hubbs and Boonstra, '97; Karels et al., 2000), whereas those in the open alpine and tundra habitats are stable (Carl, '71, Green, '77).

Our findings leave unresolved four areas that would increase our insight into the adaptations these two species have in dealing with their different life histories and living in their different habitats. First, male red squirrels have very high levels of cortisol and of MCBC and are dexamethasone resistant during the breeding season (Fig. 1), yet have high numbers of white blood cells (Table 3). Is this a species trait that occurs at other times as well (c.f. prairie voles, Taymans et al., '97) and if so, what is its purpose? Second, what hormones, if any, mediate the year-round mutually exclusive territoriality in red squirrels? Given that territoriality occurs in both sexes, it is unlikely to be mediated by testosterone. Wingfield ('94) came to the same conclusion for male song sparrows which showed year-round territoriality and suggested that it many be independent of hormones in mature birds, but that possibly there was a role for testosterone and its metabolites during development in establishing the necessary neuronal circuits. Third, testosterone levels in Arctic ground squirrels are not suppressed by stressors or are actually stimulated by them. What are the physiological mechanisms behind this resistance and what are the fitness trade-offs with this trait (i.e., does it come at the cost of lower survival subsequently)? Fourth, does the ability to handle stressors (the HPA axis and immune function) vary with reproductive state and time of year in these two species and does this ability vary with sex and social status?

\section{ACKNOWLEDGMENTS}

We thank the Natural Sciences and Engineering Research Council of Canada for providing funds to R.B. and the University of Toronto for scholarship support to C.J.M. We thank the Arctic Institute of North America, University of Calgary, for use of the facilities at the Kluane Lake Base, Yukon Territory and S.-L. Kuo and C. Coltas for help with counting the white blood cells. This is contribution number 125 of the Kluane Boreal Forest Ecosystem Project.

\section{LITERATURE CITED}

Armario A, Giralt M, Marti O, Guvalda A, Hidalgo J, Hsu BR-S, Kuh RW. 1994. The effect of acute and chronic ACTH administration on pituitary-adrenal response to acute im- 
mobilization stress: relationship to changes in corticosteroid-binding globulin. Endocrinol Res 20:139-149.

Armitage KG. 1981. Sociality as a life-history tactic of ground squirrels. Oecologia 48:36-49.

Astheimer LB, Buttener WA, Wingfield JC. 1994. Gender and seasonal differences in the adrenocortical response to ACTH challenge in an arctic passerine, Zonotrichia leucophrys gambelii. Gen Comp Endocrinol 94:33-43.

Banfield AWF. 1974. The mammals of Canada. Toronto: National Museum of Canada and University of Toronto Press.

Barnes BM. 1996. Relationship between hibernation and reproduction in male ground squirrels. In: Geiser F, Hulbert AJ, Nicol SC, editors. Adaptations to the cold: tenth international hibernation symposium. Armidale, Australia: University of New England Press. p 71-80.

Boag DA, Murie JO. 1981. Population ecology of Columbian ground squirrels in southwestern Alberta. Can J Zool 59:2230-2240.

Boonstra R, Boag PT. 1992. Spring declines in Microtus pennsylvanicus and the role of steroid hormones. J Anim Ecol 61:339-352.

Boonstra R, Singleton GR. 1993. Population declines in the snowshoe hare and the role of stress. Gen Comp Endocrinol 91:126-143.

Boonstra R, Tinnikov AA. 1998. Increased corticosteroid binding capacity of plasma albumin but not of CBG caused by ACTH induced changes in free fatty acid concentrations in snowshoe hares and rabbits. J Endocrinol 156:205-212.

Boonstra R, Krebs CJ, Kanter M. 1990. Arctic ground squirrel predation on collared lemmings. Can J Zool 68:757-760.

Boonstra R, Hik D, Singleton GR, Tinnikov A. 1998. The impact of predator-induced stress on the snowshoe hare cycle. Ecol Monogr 68:371-394.

Boutin S, Krebs CJ, Boonstra R, Dale MRT, Hannon SJ, Martin K, Sinclair ARE, Smith JNM, Turkington R, Blower M, Byrom A, Doyle FI, Doyle C, Hik D, Hofer L, Hubbs A, Karels T, Murray DL, Nams V, O'Donoghue M, Rohner C, Schweiger S. 1995. Population changes of the vertebrate community during a snowshoe hare cycle in Canada's boreal forest. Oikos 74:69-80.

Bradley A. 1987. Stress and mortality in the red-tailed Phascogale Phascogale calura (Marsupialia: Dasyuridae). Gen Comp Endocrinol 67:85-100.

Bradley A. 1990. Failure of glucocorticoid feedback during breeding in the male red-tailed phascogale Phascogale calura (Marsupialia: Dasyuridae). J Steroid Biochem Mol Biol 37:155-163.

Bradley AJ, McDonald IR, Lee AK. 1980. Stress and mortality in a small mammal (Antechinus stuartii MacLeay). Gen Comp Endocrinol 40:188-200.

Brien TG. 1981. Human corticosteroid binding globulin. Clin Endocrinol 14:193-212.

Bullock BL, Rosendahl PP. 1984. Pathophysiology. Boston: Little, Brown and Co.

Byrom AE. 1997. Population ecology of Artic ground squirrels in the boreal forest during the decline and low phases of the snowshoe hare cycle. PhD thesis, University of British Columbia, Vancouver, British Columbia.

Carl EA. 1971. Population control in arctic ground squirrels. Ecology 52:395-413.

Christian JJ. 1970. Social subordination, population density, and mammalian evolution. Science 168:84-90.

Chrousos GP, Renquist D, Brandon D, Eil C, Pugeat M, Vigersky R, Culter GB Jr, Loriaux DL, Lipsett MB. 1982. Glucocorticoid hormone resistance during primate evolution: receptor-mediated mechanisms. Proc Natl Acad Sci 79:20362040.

Chrousos GP, Detera-Wadleigh SD, Karl M. 1993. Syndromes of glucocorticoid resistance. Ann Intern Med 119:1113-1124.

Creel S, Creel NM, Monfort SL. 1996. Social stress and dominance. Nature 379:212.

Creel S, Creel NM, Mills MGL, Monfort SL. 1997. Rank and reproduction in cooperatively breeding African wild dogs: behavioral and endocrine correlates. Behav Ecol 82:98-306.

Dallman MF, Akana SF, Cascio CS, Darlington DN, Jacobson L, Levin N. 1990. Regulation of ACTH secretion: variations on a theme of B. Recent Prog Horm Res 43:113-173.

Day RW, Quinn GP. 1989. Comparisons of treatment after an analysis of variance in ecology. Ecol Monogr 59:433-463.

Debro JR, Traver H, Korner A. 1957. The determination of serum albumin and globulin by a new method. J Lab Clin Med 50:728-732.

Englund PT, Huberman JA, Jovin TM, Kornberg A. 1969. Enzymatic synthesis of deoxyribonucleic acid: XXX. Binding of triphosphates to deoxyribonucleic polymerase. J Biol Chem 244:3038-3044.

Finch CE, Rose MR. 1995. Hormones and the physiological architecture of life history evolution. Q Rev Biol 70:1-52.

Fleshner M, Deak T, Spenncer RL, Laudenslager ML, Watkins LR, Maier SF. 1995. A long term increase in basal levels of corticosterone and a decrease in corticosteroid-binding globulin after acute stressor exposure. Endocrinology 136:53365342

Gagnon J, Roth J, Finzer B, Hofmann R, Haycock K, Simpson J, Feldman D. 1991. SuperANOVA: accessible general linear modelling. Berkeley, CA: Abacus Concepts, Inc.

Green JE. 1977. Population regulation and annual cycles of activity and dispersal in the Arctic ground squirrel. MSc. thesis, University of British Columbia, Vancouver, British Columbia.

Greenberg N, Wingfield JC. 1987. Stress and reproduction: reciprocal relationships. In: Norris DO, Jones RE, editors. Hormones and reproduction in fishes, amphibians, and reptiles. New York: Plenum Press. p 461-503.

Gurnell J. 1987. The natural history of squirrels. London: Christopher Helm.

Hafner DJ. 1984. Evolutionary relationships of the nearctic sciuridae. In: Murie JO, Michener GR, editors. The biology of ground-dwelling squirrels. Lincoln: University of $\mathrm{Ne}-$ braska Press. p 1-23.

Hellgren EC, Rogers LL, Seal US. 1993. Serum chemistry and hematology of black bears: physiological indices of habitat quality or seasonal patterns. J Mammal 74:304-315.

Holekamp KE, Sherman PW. 1989. Why male ground squirrels disperse. Am Sci 77:232-239.

Holekamp KE, Talamantes F. 1992. Seasonal fluctuations in hormones and behavior of free-living male California ground squirrels (Spermophilus beldingi). Horm Behav 26:7-23.

Hubbs AH, Boonstra R. 1997. Population limitation in Arctic ground squirrels: effects of food and predation. J Anim Ecol 66:527-541.

Hubbs AH, Karels T, Byrom A. 1996. Tree-climbing by arctic ground squirrels, Spermophilus parryii, in the Southwestern Yukon Territory. Can Field Nat 110:533-534.

Kalin NH, Cohen Rm, Kraemer GW, Risch SC, Shelton S, Cohen M, McKinney WT, Murphy DL. 1981. The dexamethasone suppression test as a measure of hypothalamicpituitary feedback sensitivity and its relationship to behavioral arousal. Neuroendocrinology 32:92-95.

Karels T, Byrom AE, Boonstra R, Krebs CJ. 2000. The inter- 
active effects of food and predators on reproduction and overwinter squirrel of Artic ground squirrels. J Anim Ecol 69: (in press).

Keightley M-C, Fuller PJ. 1996. Anomalies in the endocrine axes of the guinea pig: relevance to human physiology and disease. Endocrine Rev 17:30-44.

Keith LB. 1990. Dynamics of snowshoe hare populations. Curr Mammal 2:119-195.

Keller SE, Schleifer SJ, Stein M. 1984. Stress-induced suppression of lymphocyte function in rats. In: Cooper EL, editor. Stress, immunity, and aging. New York: Marcel Dekker Inc. p 109-121.

Kelley KW. 1985. Immunological consequences of changing environmental stimuli. In: Moberg GP, editor. Animal stress. Baltimore, MD: American Physiological Society. p 193-223.

Kemp GA, Keith LB. 1970. Dynamics and regulation of red squirrel (Tamiasciurus hudsonicus) populations. Ecology 51:763-779.

Keppel G. 1982. Design and analysis. A researcher's handbook. 2nd ed. Englewood Cliffs, NJ: Prentice-Hall.

Klein SL, Taymans SE, DeVries AC, Nelson RJ. 1996. Cellular immunity is not compromised by high serum corticosterone concentrations in prairie voles. Am J Physiol 271: R1608-R1613.

Krebs CJ, Gilbert BS, Boutin S, Sinclair ARE, Smith JNM. 1986. Population biology of snowshoe hares: I. Demography of food-supplemented populations in the southern Yukon, 1976-84. J Anim Ecol 55:963-982.

Krebs CJ, Boutin S, Boonstra R, Sinclair ARE, Smith JNM, Dale MRT, Martin K, Turkington R. 1995. Impact of food and predation on the snowshoe hare cycle. Science 269:11121115.

Lacey EA. 1991. Reproductive and dispersal strategies of male Arctic ground squirrels (Spermophilus parryii plesius). $\mathrm{PhD}$ thesis. University of Michigan, Ann Arbor.

Lacey EA, Wieczorek JR, Tucker PK. 1997. Male mating behaviour and patterns of sperm precedence in Arctic ground squirrels. Anim Behav 53:767-779.

Larsen KW, Boutin S. 1994. Movements, survival, and settlement of red squirrel (Tamiasciurus hudsonicus) offspring. Ecology 75:214-223.

Laurell S, Tibbling G. 1967. Colorimetric micro-determination of free fatty acids in plasma. Clin Chim Acta 16:57-62.

Lee AK, Cockburn A. 1985. Evolutionary ecology of marsupials. Cambridge: Cambridge University Press.

Lee AK, McDonald IR. 1985. Stress and population regulation in small mammals. Oxford Rev Reprod Biol 7:261-304.

Levine S, Coe C, Wiener SG. 1989. Psychoneuroendocrinology of stress: a psychobiological perspective. In: Brush FR, Levine S, editors. Psychoendocrinology. San Diego: Academic Press. Inc., p 341-377.

Lincoln BJ. 1972. Behavior study of the Arctic ground squirrel, Citellus parryi plesius. Icefield Ranges Res Proj Sci 3:245-253.

Lochmiller RL, Hellgren EC, Varner LW, Grant WE. 1986. Serum and urine biochemical indicators of nutritional status in adult female collared peccaries, Tayassu tajacu (Tayassuidae). Comp Biochem Physiol 83A:477-488.

MacHutchon AG, Harestad AS. 1990. Vigilance behaviour and use of rocks by Columbian ground squirrels. Can J Zool 68:1428-1432.

Mann DR, Orr TE. 1990. Effect of restraint stress on gonadal proopiomelanocortin peptides and the pituitary-testicular axis in rats. Life Sci 46:1601-1609.

Martins EP, Hansen TR. 1996. The statistical analysis of in- terspecific data: a review and evaluation of phylogenetic comparative methods. In: Martins EP, editor. Phylogenies and the comparative method in animal behavior. New York: Oxford University Press. p 22-75.

McColl CJ. 1998. The role of food, predation, and population density on the stress physiology of Artic ground squirrels. MSc thesis, University of Toronto, Toronto, Ontario.

McColl CJ, Boonstra R. 2000. The physiological effect of three inhalant anesthetics on Arctic ground squirrels. Wildl Soc Bull 28:(in press).

McDonald IR, Lee AK, Bradley AJ, Than KA. 1981. Endocrine changes in dasyurid marsupials with differing mortality patterns. Gen Comp Endocrinol 44:292-301.

McDonald IR, Lee AK, Than KA, Martin RW. 1986. Failure of glucocorticoid feedback in males of a population of small marsupials (Antechinus swainsonii) during a period of mating. J Endrocrinol 108:63-68.

McEwen BS, Brinton RW, Sapolsky RM. 1988. Glucocorticoid receptors and behavior: implications for the stress response. Adv Exp Med Biol 245:35-45.

McLean IG. 1985. Seasonal patterns and sexual differences in the feeding ecology of Arctic ground squirrel (Spermophilus parryii plesius). Can J Zool 63:1298-1301.

McLean IG, Towns AJ. 1981. Differences in weight changes and the annual cycle of male and female arctic ground squirrels. Arctic 34:249-254.

Michael SE. 1962. The isolation of albumin from blood serum or plasma by means of organic solvents. Biochem $\mathrm{J}$ 82:212-218.

Michener GR. 1983. Kin identification, matriarchies, and the evolution of sociality in ground-dwelling sciurids. In: Eisenberg JF, Kleiman DG, editors. Advances in the study of behavior. Am Soc Mammalogists Special Pub no. 7. $\mathrm{p}$ 528-572.

Michener GR, McLean IG. 1996. Reproductive behaviour and operational sex ratio in Richardson's ground squirrels. Anim Behav 52:743-758.

Miller WL, Tyrrell JB. 1995. The adrenal cortex. In: Felig P, Baxter JD, Frohman LA, editors. Endocrinology and metabolism. 3rd ed. New York: McGraw-Hill Inc. p 555-711.

Monaghan EP, Glickman SE. 1992. Hormones and aggressive behavior. In: Becker JB, Breedlove SM, Crews D, editors. Behavioral endocrinology. Cambridge, MA: MIT Press. p 261-285.

Munck A, Guyre P, Holbrook N. 1984. Physiological functions of glucocorticoids during stress and their relation to pharmacological actions. Endocrine Rev 5:25-44.

Obbard ME. 1987. Red squirrel. In: Novak M, Obbard ME, Malloch ME, editors. Wild furbearers: management and conservation in North America. Toronto: Ontario Ministry of Natural Resources. p 265-281.

O'Donoghue M. 1994. Early survival of juvenile snowshoe hares. Ecology 75:1582-1592.

O'Donoghue M, Boutin S. 1995. Does reproductive synchrony affect juvenile survival rates of northern mammals? Oikos 74:115-121.

Paterson JYF, Hills F. 1967. The binding of cortisol by ovine plasma proteins. J Endocrinol 37:261-268.

Price K, Boutin S, Ydenberg R. 1990. Intensity of territorial defense in red squirrels: an experimental test of the asymmetric war of attrition. Behav Ecol Sociobiol 27:217-222.

Redei E, Li L, Halasz I, McGivern RF, Aird F. 1994. Fast glucocorticoid feedback inhibition of ACTH secretion in the ovariectomized rat: effect of chronic estrogen and progesterone. Neuroendocrinology 60:113-123. 
Rosner W. 1990. The functions of corticosteroid-binding globulin and sex hormone-binding globulin: recent advances. Endocrine Rev 11:80-91.

Rusch SA, Reeder WG. 1978. Population ecology of Alberta red squirrels. Ecology 59:400-420.

Sapolsky R. 1983. Individual differences in cortisol secretory patterns in the wild baboon: role of negative feedback sensitivity. Endocrinology 113:2263-2267.

Sapolsky R. 1985. Stress induced suppression of testicular function in the wild baboon: role of glucocorticoids. Endocrinology 116:2273-2278.

Sapolsky R. 1992. Neuroendocrinology of the stress-response. In: Becker JB, Breedlove SM, Crews D, editors. Cambridge, MA: MIT Press. p 287-324.

Scatchard G. 1949. The attractions of proteins for small molecules and ions. Ann NY Acad Sci 51:827-841.

Schoech SJ, Mumme RL, Moore MC. 1991. Reproductive endocrinology and mechanisms of breeding inhibition in cooperatively breeding Florida scrub jays (Aphelocoma $c$. coerulescens). Condor 93:354-364.

Scott MP, Tan TN. 1985. A radiotracer technique for the determination of male mating success in natural populations. Behav Ecol Sociobiol 17:29-33.

Seggie JA, Brown GM. 1974. Stress response patterns of plasma corticosterone, prolactin, and growth hormone in the rat, following handling or exposure to novel environment. Can J Physiol Pharmacol 53:629-637.

Selye H. 1946. The general-adaptation-syndrome and diseases of adaptation. J Clin Endrocrinol Metab 6:117-230.

Seralini G-E, Underhill CM, Smith CL, Nguyen VTT, Hammond GL. 1989. Biological half-life and transfer of maternal corticosteroid-binding globulin to amniotic fluid in the rabbit. Endocrinology 125:1321-1325.

Silverin B, Arvidsson B, Wingfield J. 1997. The adrenocortical responses to stress in breeding willow warblers Phylloscopus trochilus in Sweden: effects of latitude and gender. J Anim Ecol 11:376-384.

Smith CC. 1968. The adaptive nature of social organization in the genus of three squirrels Tamiasciurus. Ecol Monogr 38:31-63.

Smith CL, Hammond GL. 1991. Ontogeny of corticosteroidbinding globulin biosynthesis in the rat. Endocrinology 128:938-988.
Smith JH, Bubenik GA. 1990. Plasma concentrations of glucocorticoids in white-tailed deer: the effect of acute ACTH and dexamethasone administration. Can J Zool 68:2123-2129.

Smith MC. 1968. Red squirrel responses to spruce cone failure in interior Alaska. J Mammal 32:305-317.

Southwood TRE. 1977. Habitat, the template for ecological strategies? J Anim Ecol 46:337-366.

Southwood TRE. 1988. Tactics, strategies and templates. Oikos 52:3-18.

Stearns SC. 1992. The evolution of life histories. Oxford, UK: Oxford University Press.

Stuart-Smith AK, Boutin S. 1995. Predation on red squirrels during a snowshoe hare decline. Can J Zool 73:713-722.

Tait JR, Burstein S. 1964. In vivo studies of steroid dynamics in man. In: Pincus G, Thinman KV, Astwood EB, editors. The hormones. Vol. 5. New York: Academic Press. p 441-557.

Taymans SE, DeVries AC, DeVries MB, Nelson RJ, Friedman TC, Castro M, Detera-Wadleigh S, Carter CS, Chrousos GP. 1997. The hypothalamic-pituitary-adrenal axis of prairie vole (Microtus ochrogaster): evidence for target tissue glucocorticoid resistance. Gen Comp Endocrinol 106:48-61.

Vinson GP, Renfree MB. 1975. Biosynthesis and secretion of testosterone by adrenal tissue from North American opossum Didelphis virginiana and the effects of trophic hormone stimulation. Gen Comp Endocrinol 27:214-222.

Winer BJ. 1971. Statistical principles in experimental design. 2nd ed. New York: McGraw-Hill.

Wingfield JC. 1994. Control of territorial aggression in a changing environment. Psychoneuroendocrinology 19:709-721.

Wingfield JC, Hegner RE, Lewis DM. 1991. Circulating levels of luteinizing hormone and steroid hormones in relation to social status in the cooperatively breeding white-browed sparrow weaver, Plocepasser mahali. J Zool Lond 225: 43-58.

Yahr P. 1983. Hormonal influences on territorial marking behavior. In: Svare BB, editor. Hormones and aggressive behavior. New York: Plenum Press. p 145-175.

Yamamoto S, Utsu S, Tanioka Y, Ohsawa N. 1977. Extremely high levels of corticosteroids and low levels of corticosteroid binding macromolecule in plasma of marmoset monkeys. Acta Endocrinol 85:398-405. 